\title{
Proposed Model of Hand for Designing Ergonomic Vibration Isolation Systems for Hand-held Impact Tools
}

\author{
Michał Śledziński* \\ Chair of Machine Design Fundamentals, Poznan University of Technology, Poznań, Poland \\ *Corresponding author: michal.sledzinski@put.poznan.pl
}

Received October 23, 2014; Revised October 30, 2014; Accepted November 12, 2014

\begin{abstract}
This article presents the methodology of ergonomic design and testing of hand-held impact tools with vibration isolation systems. An operator's hand model is proposed comprising uniform bars positioned at angles adequate to the working position of the upper extremity during soil compacting operation. The model is addressing both the subject operator's anthropometric traits and the tool's interaction with the system. Model testing data of the hand-arm system are in good agreement with the results of experimental testing, in which the level of accelerations measured both at the tool handle and at the most exposed areas of the hand, that is at the wrist and at the elbow, were determined using miniature triaxial vibration sensors. The presented hand-arm system model makes it possible to analyze interaction between the hand and the tool and transmission of vibration from the tool to the human body. The proposed methodology may be used in creating ergonomic working environments and in designing safe impact tools.
\end{abstract}

Keywords: hand model, simulation, impact tools

Cite This Article: Michał Śledziński, "Proposed Model of Hand for Designing Ergonomic Vibration Isolation Systems for Hand-held Impact Tools.” American Journal of Mechanical Engineering, vol. 2, no. 7 (2014): 290-294. doi: 10.12691/ajme-2-7-25.

\section{Introduction}

The subject of the analysis are pneumatically driven hand-held impact tools and their vibration isolation systems. The first tools of this type were built by Jonathan J. Couch and Joseph W. Fowle as early as between 1848 and 1851. While improving working performance these tools had also adverse effects on human health due to exposure of operators to harmful vibration. The first reports on disease symptoms in pneumatic drill operators were provided by Loriga in 1910 [9]. In $1955 \mathrm{E}$. Andreeva-Galanina introduced the term "vibration disease. Vibration transmitted to human body may assume the form of the so-called local vibration (hand-arm vibration) characteristic of vibrations having an effect directly on human hands.

Pneumatic impact tools are not only a source of vibration harmful to humans and to the environment but also generate high intensity noise often exceeding the 100$130 \mathrm{~dB}$ range. The sources of noise include flow of compressed air through nozzles and operating chambers and the hitting the material by the tool foot. The tool designers are required to eliminate or considerably minimize the associated health and safety hazard factors.

\section{Methodology of Ergonomic Design of Hand-Held Impact Tools}

The purpose the ergonomic design of impact tools is to ensure optimal working environment for the operators. As far as hand-held impact tools are concerned of particular importance are the individual traits of the operator, properties of the tool and of the process, and the material parameters of the working environment such as:

- $\quad$ the tool (design, working condition),

- $\quad$ technological process (type of operation, medium undergoing compaction),

- $\quad$ vibration (intensity, frequency, direction),

- exposure (duration of impact, protective measures), and

- $\quad$ individual traits of the operator (skill to damp vibrations, the way of tool handling).

If the allowable limits of the above-mentioned factors are exceeded, the operator may be exposed to potential vibration disease hazard.

The recent technical and technological progress has lead to a shift from the producer's market to the end-user's market, and currently we can speak about HumanCentered Design. This ergonomic approach to design puts man at the centre and sees him as the subject of activity to which main design objectives are subordinated $[4,8,18]$.

In the design of hand-held impact tools however engineers face a difficult problem. On the one hand their aim is to minimize harmful effect of vibration on the operator but, on the other hand, they need to ensure the tool's high vibration intensity necessary for proper performance in the technological process.

In human-centered design of impact tools one should aim at identifying the device's features important for the 
user and environment (operating comfort, immediate and long-term safety, e.g., effect of vibration and noise). In the light of the requirements imposed on the modern ergonomic design a methodology of design [21] and testing [22] of impact tools and their damping systems was developed. It is presented in the form of diagrams in Figure 1 and Figure 2.

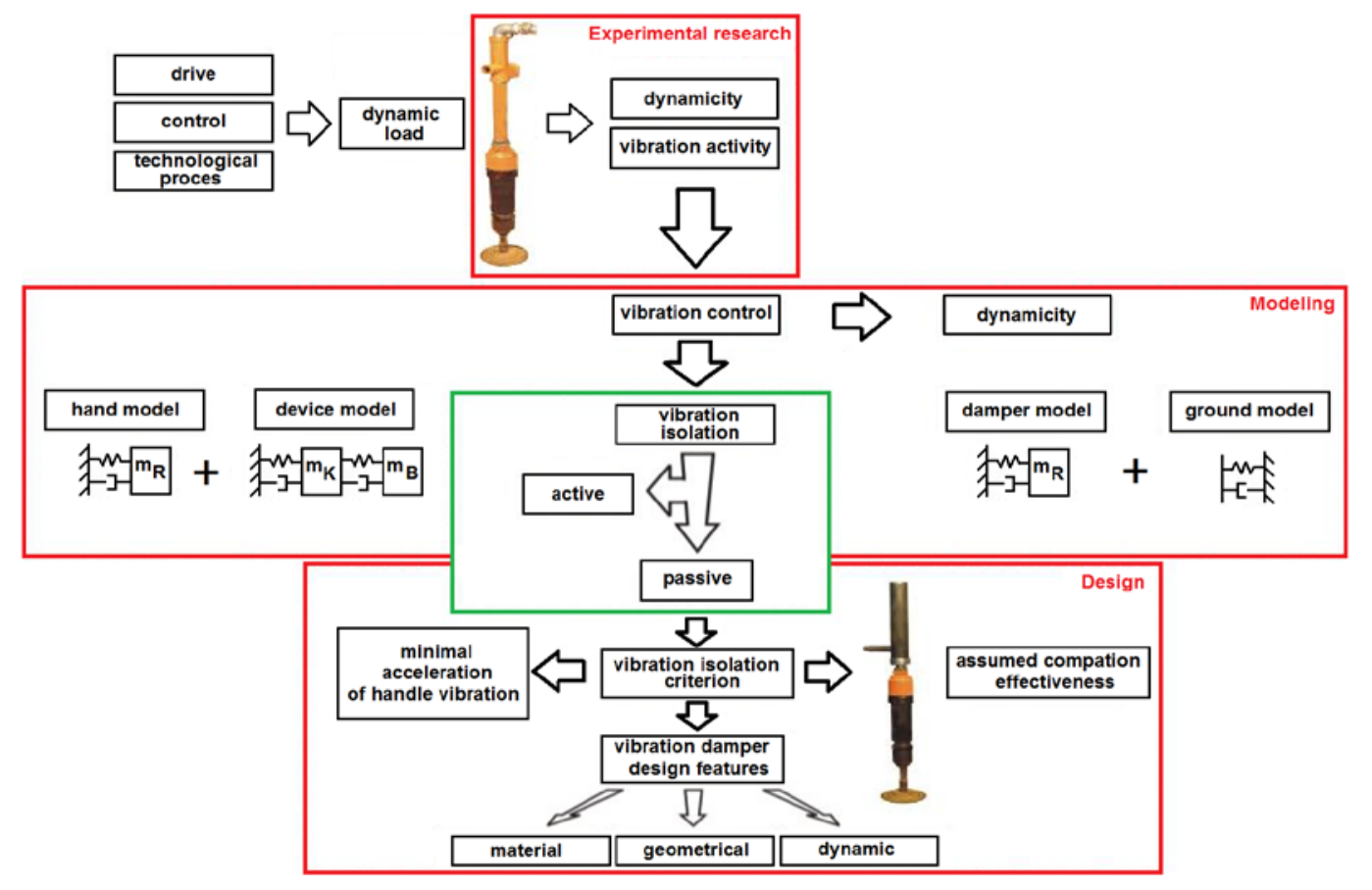

Figure 1. Methodology of design of hand-held impact tools and their vibration isolation systems [21]

The algorithm of methodology of design and testing of impact tools (Figure 1) was developed based on own analyses and research. The status of the tool's dynamic loads is determined at the preliminary stage. The determined level of vibration activity is then compared with the maximum allowable values set out in standards, machine safety regulations and EU directives. When the tool vibrations level exceeds allowable values the solution searching stage starts and a decision on possible interference into the source of vibration or on use of vibration isolation is taken. If a damping system is the solution to be adopted, the type of vibration isolation is specified, meaning it is indicated whether passive or active isolation is to be applied.

The next design stage involves mathematical modeling, comprising all the components of the man - impact tool ground system. Vibration isolation criteria, i.e. achieving minimum acceleration of vibration of the handle without reducing the effectiveness of the compaction process, are established. Then the design features are selected and a vibration damper prototype is built.

The vibration isolation system prototype needs to be verified experimentally from the anthropo-technical perspective (Figure 2). Work at this stage is particularly oriented to protecting humans by reducing transmission of vibration from the tool to the operator's hand-arm system.

Tool testing, in compliance with the standard recommendations, was conducted by taking measurements of acceleration values on the vibration isolator's handle and at the same time the testing scope was expanded by the measurements of the element's displacement. However, the scope of testing recommended in standard normative procedures was evaluated as incomplete and insufficient. For this reason measurement of accelerations occurring on the directly exposed parts of the hand were taken simultaneously using miniature triaxial acceleration sensors ADXL325 [22].

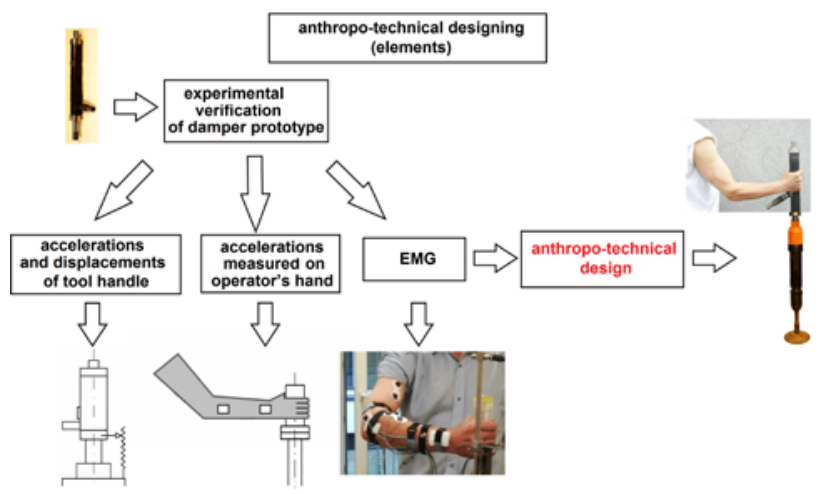

Figure 2. Methodology of testing of impact tool damping system prototypes (from anthropo-technical perspective) [22]

An important part of the ergonomic designing cycle is modeling of the analyzed system. Modeling makes it possible to analyze various structural concepts as early as at the designing stage and to study influence of individual material, geometric and dynamic tool features on its behavior $[7,20]$.

Modeling of biomechanical systems is an important part of the ergonomic engineering process.

\section{Biomechanical System Modeling}

In the designing process it is necessary to describe biodynamic traits of the human body in mathematical terms.

The conventional approach to hand-arm system modeling with the objective to analyze the system's 
biodynamics usually boils down to the use of lumpedmass mechanical models with elements of spring-damper type [16,19], or distributed-mass models [25]. However, biomechanical model designing should address also broadly understood ergonomic aspects: working environment, tool's characteristics and its vibration activity, vibration parameters, and also the operator's anthropometric data and his technique of tool handling.

When analyzing the effect of vibration on the human body, the body is treated as a vibrating, elastic system with a considerable ability to damp vibration. In the dynamic analysis of the behavior of the body of a person operating a tool it is necessary to take into account the working position [1] as it is related with the change in elastic properties and the position of the centre of gravity of the body or its part.

The biomechanical parameters used in model testing are given in numerous studies $[3,10,17]$. However, their values tend to differ significantly and the conditions in which they were determined are usually not specified. This makes an analysis and comparison difficult and the adoption of these parameters in new research impossible. Therefore, one should attempt to determine anthropometric parameters and parameters describing the behavior of the hand-arm biomechanical system that are adequate for the specific tool, technological process and operator and his specific tool handling technique.

Modeling of the hand-tool handle system for tool movement in horizontal plane was the subject of studies $[3,10,14,15,26]$.

Considering the impact tool for soil compaction working in the vertical plane, being the object of the analysis a mathematical model of the hand-arm system with distributed parameters, adequate for the working movement performed, was developed.

One of the first models of a pneumatic drill operator's upper extremity was the model proposed by Kuchna (1953). In this model the hand was modeled with big approximation with a linear damping element. Dieckmann's model (1958) represented the position of the hand characteristic of working with a demolition hammer. The parameters of this model were selected based on experimental studies. Next attempts to develop models were undertaken by Miwa (1964), based on the system's impedance study, Vasilev (1972) - for different angles between the hand and the arm and Reynolds (1975), who developed a three degree-of-freedom discrete system describing the hand's dynamic characteristics. From more recent models, one may mention Fritz model (1991), and Daikoku and Ishikawa model (1990) based on the studies of hand impedance noted for different ways of tool handling. Dong et al. (2005) presented a two-dimensional MES model of fingers of the hand used in the analysis of transmission of vibrations to the hand-arm system. Kazi (2008) developed a two and tree-mass model of the hand for researching biodynamic reactions in a vibrating environment. Joshi and Murray (2010) proposed a model with single degree of freedom in rotation used in biodynamic analysis of connecting elements with bolted joints. Dong and Welcome et al. (2013) dealt with a fourdegree-of-freedom lumped-parameter model used in the analysis of vibration damping by personal protection equipment used by workers operating impact tools.

\section{Proposed Hand Model}

Following numerous attempts to build a model representing as close as possible the actual behavior of the hand-arm system in relation to a given tool, the working conditions and the particular operator a biomechanical model shown in Figure 3 and Figure 4 was developed.

This model has the form of a system of uniform bars with distributed masses representing angular position of the bent upper extremity during operation of an impact tool. In this model the individual bars represent, respectively, the operator's arm, forearm and hand. The articulations connecting the bars correspond with shoulder and elbow joints and represent the wrist and the hand fingers-handle coupling. The action of the upper part of the operator's body (segment I, Figure 4) on the hand-arm system and of the operator's hand on the tool (segment V, Figure 4) is described with viscoelastic connections (Kelvin-Voigt model).

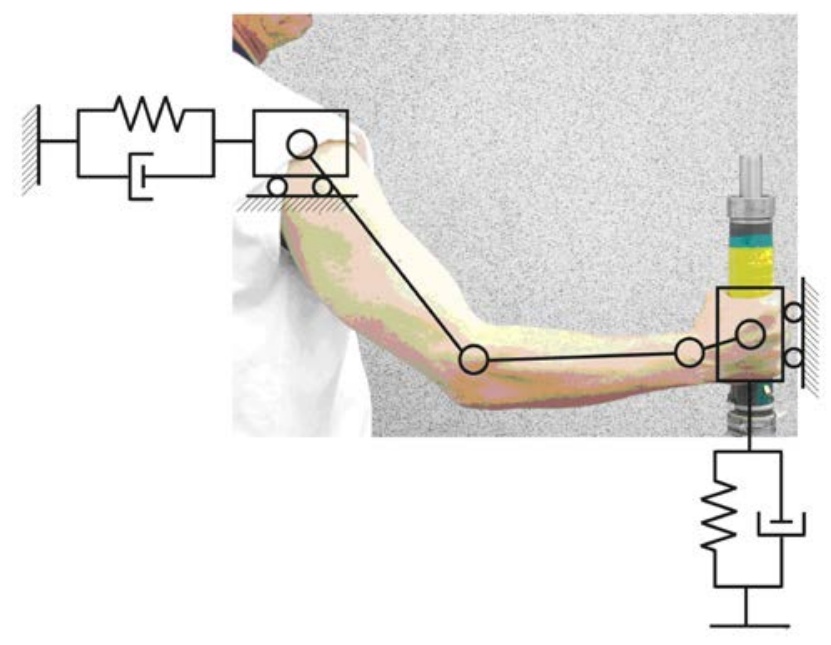

Figure 3. Operator's hand-arm model -three-segment bar system in the form of a triple pendulum

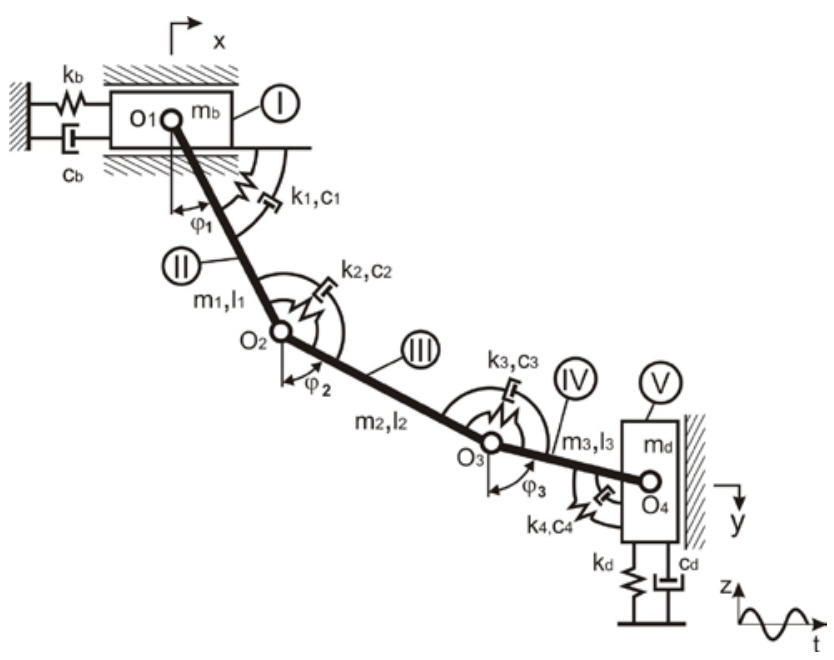

Figure 4. The model's diagram with description of parameters: 1 - length, $\mathrm{m}$ - mass, $\mathrm{k}$ - stiffness coefficient, c - damping coefficient; symbols of parameters: b - shoulder, 1 - arm, 2 - forearm, 3 - hand, 4 - hand fingers; symbols of systems: I - shoulder, II - arm, III - forearm, IV hand, $\mathrm{V}$ - fingers of the hand, $\varphi$ - initial angle

The model was described with equations of motion using the Lagrange method [22]. 


\section{Simulation Analyses and Experimental Verification of the Model}

The developed model was used to carry out simulation analyses of the operator's hand action on the tool and to study the degree of vibration reduction by the vibration isolation system. Following numerical solving of differential equations describing the model with the Runge-Kutta fourth order method simulation analyses were made. After the preliminary identification of the model the following parameter values determined for the tool operator participating in the tests were adopted for the analysis: $\mathrm{mb}=4 \mathrm{~kg}$ - mass of the shoulder, $\mathrm{kb}=180 \mathrm{~N} / \mathrm{m}$ - stiffness of the spring for the shoulder, $c b=8 \mathrm{Ns} / \mathrm{m} \mathrm{-}$ viscous damping of the shoulder, $\mathrm{m} 1=2.45 \mathrm{~kg}$ - shoulder mass, $\mathrm{k} 1=45 \mathrm{Nm}-$ stiffness of the arm spring, $\mathrm{c} 1=5.5$ Nms - viscous damping, $11=0.32 \mathrm{~m}$ - length of bar representing the arm, $\mathrm{m} 2=1,3 \mathrm{~kg}-$ forearm mass, $\mathrm{k} 2=25$ $\mathrm{Nm}$ - stiffness of the spring, c2 $=4 \mathrm{Nms}-$ viscous damping, $12=0.26 \mathrm{~m}$ - forearm length, $\mathrm{m} 3=0.45 \mathrm{~kg}-$ mass of the hand, $\mathrm{k} 3=10 \mathrm{Nm}$ - stiffness of the spring, c3 $=2 \mathrm{Nms}-$ viscous damping, $13=0.1 \mathrm{~m}-$ hand length .

Figure 5 to Figure 9 show selected diagrams of changes in displacements and accelerations of the modeled hand segments.

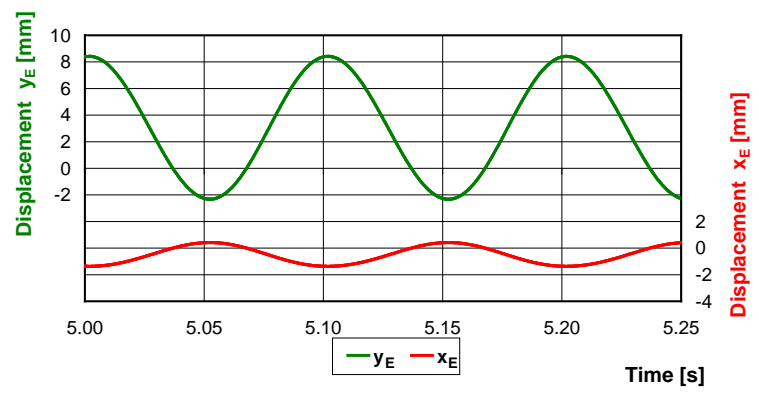

Figure 5. Changes in linear displacements of the elbow of the hand model in horizontal direction $\mathrm{x}_{\mathrm{E}}$ and in vertical direction $\mathrm{y}_{\mathrm{E}}$

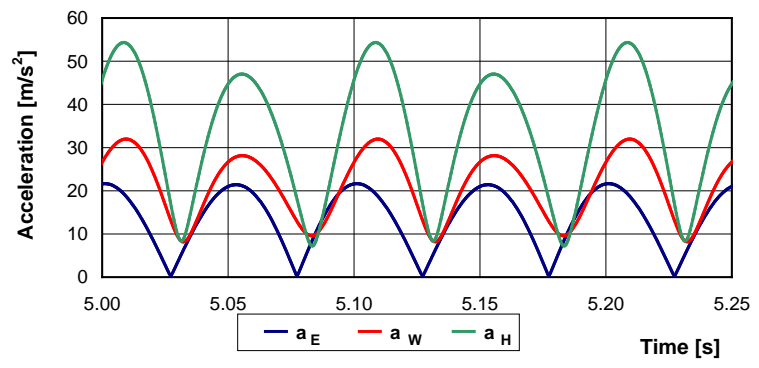

Figure 6. Changes in resultant accelerations of the hand $\mathrm{a}_{\mathrm{H}}$, wrist $\mathrm{a}_{\mathrm{w}}$ and elbow of the model of the hand $a_{\mathrm{E}}$

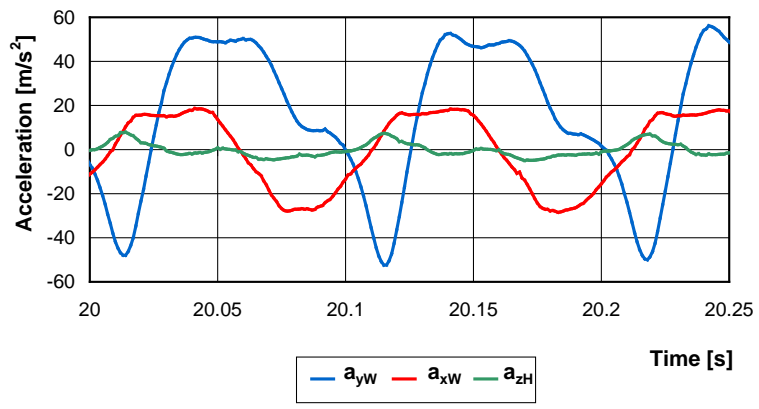

Figure 7. Accelerations from experimental measurements on the wrist: in horizontal direction $\mathrm{a}_{\mathrm{xW}}$, vertical direction $\mathrm{a}_{\mathrm{yw}}$ and in the direction transverse to the hand plane $\mathrm{a}_{\mathrm{zH}}$

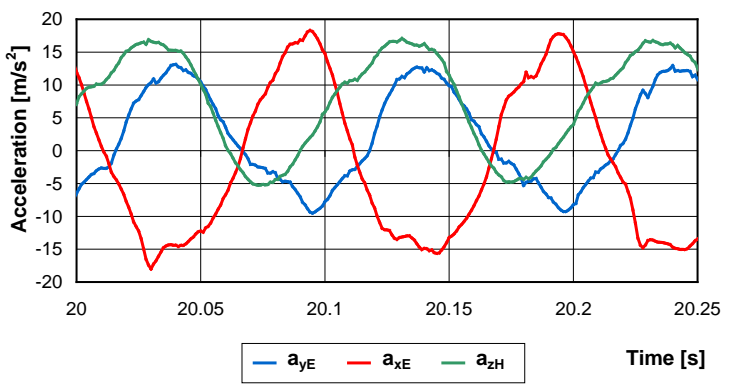

Figure 8. Accelerations from experimental measurements on the elbow: in the horizontal direction $\mathrm{a}_{\mathrm{xE}}$, in the vertical direction $\mathrm{a}_{\mathrm{yE}}$ and in the direction transverse to the plane of the hand $\mathrm{a}_{\mathrm{zH}}$

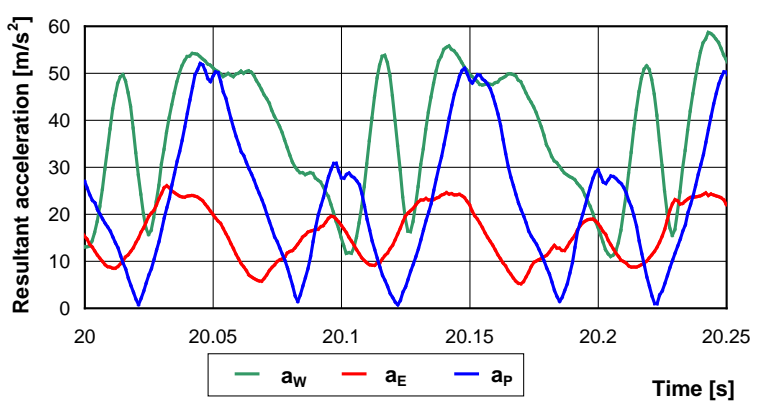

Figure 9. Changes in resultant accelerations on the operator's wrist $a_{w}$, elbow $\mathrm{a}_{\mathrm{E}}$ and piston of the inductor $\mathrm{a}_{\mathrm{P}}$ during experimental testing

Analysis of the model and experimental testing results demonstrated a fairly good agreement between the values of the measured working parameters, which may be a confirmation of the usefulness of the proposed model for the analysis of the hand-arm system behavior and for selection of adequate parameters of the system damping the transmission of vibration to the human body. The noted differences result from unavoidable artifacts related with dynamic measurements (movement of the extremity) and with the fastening of the acceleration sensors on the skin of the hand.

\section{Summing up}

The developed methodology of design and testing of vibration isolation systems for impact tools was verified by developing and building of vibration isolators allowing for a considerable reduction of vibration transmitted to the human hand-arm system [21,22]. Effective vibration control, and hence minimized exposure of operators to harmful effects while working with impact tools without compromising the effectiveness of soil compaction working process, can confirm correctness of the proposed methodology of designing, testing and modeling of vibration isolation systems. The presented methodological approach to designing of an ergonomic working environment with manually operated impact tools and in a way covering all the elements of the man-tool anthropotechnical system, as well as the proposed hand model adequate for individual traits of a given man, the tool under study and the working process may be used with success in testing and designing new and verification of existing hand-held impact tools. The presented results may contribute to improving the occupational health and safety of operators, better comfort of work, higher accuracy and effectiveness of the technological process, and 
significantly reduce the impact of vibration on human health, and, as a result, reduce the incidence of occupational diseases, including in particular vibration disease.

\section{References}

[1] Adewusi, S., Rakheja, S., Marcotte, P., Biomechanical models of the hand-arm to simulate distributed biodynamic response for different postures, International Journal of Industrial Ergonomics, Vol. 42. 2012.

[2] Chaffin, D.B., Anderson, G.B.J., Martin, B.J., Occupational Biomechanics, Wiley-Interscience, New Jersey, 2006.

[3] Cherian, T.H., Control of hand transmitted vibration through development and analysis of a human hand-arm-isolator model, A thesis, Concordia University, Montreal, Quebec, 1994.

[4] Dietrych, J., Projektowanie i konstruowanie, WNT, Warszawa, 1974.

[5] Dong, R.G., Wu J.Z., Welcome D.E., Recent advances in biodynamics of human hand-arm system, Industrial Health, 43.

[6] Dong, R.G., Welcome, D.E., McDowell, T.W., Wu, J.Z., Modeling of the biodynamic responses distributed at the fingers and palm of the hand in three orthogonal directions, Journal of Sound and Vibration, 332 (4), 2013.

[7] Foster, M., Sztuka modelowania układów dynamicznych, Warszawa, WNT, 1996.

[8] Gause, D.C., Minch, E., Procesy projektowe z perspektywy przestrzeni stanów, Projektowanie i systemy: zagadnienia metodologii. T. 12, Ossolineum, Warszawa, 1990.

[9] Grzegorczyk, L., Walaszek, M., Drgania i ich oddziatywanie na organizm ludzki, PZWL, Warszawa, 1971.

[10] Gurram, R., A study of vibration response characteristics of the human hand-arm system, A thesis, Concordia University, Montreal, Quebec, 1993.

[11] Joshi, A., Leu, M.C., Murray, S., Modeling of hand-arm system for studying the dynamic effect of impact generated by fastening of shear-type fasteners, Proceedings of $4^{\text {th }}$ Annual ISC Research Symposium ISRS 2010, April 21, 2010, Rolla, Missouri.

[12] Jurczak, M., Wibracje, PWN, Warszawa, 1974.
[13] Kaz,i S., As'arry, A., Zain, M.Z. et al., Biodynamic response of human hand-arm models under vibration, 10th WSEAS Int. Conf. on Automatic Control, Modelling and Simulation ACMOS'08, Istanbul, 2008.

[14] Kinne, J., Latzel, K., Melzig-Thiel, R., Schatte, M., Schwingungstechnische Modellierung der beiden Hand-ArmSystem von Bedienpersonen für die Anwendung bei der Prüfung von Handmaschinen, Forschung Projekt Fb 1955, Dortmund, Berlin, Dresden, 2011.

[15] Marcotte, P., Adewusi, S., Boutin, J., Nelisse, H., Modelling the contributions of handle dynamics on the biodynamic response, 11th International Conference On Hand-Arm Vibration, Bolonia, 2007.

[16] Mishoe, J.W., Suggs, C.W., Vibrational responses of human hand, Journal of Sound and Vibration, 53, 4, 1977.

[17] Meltzer, G., Melzig-Thiel, R., Schatte, M., Ein mathematisches Schwingungsmodell für das menschliche Hand-Arm-System, Maschinenbautechnik, 29, 1980

[18] Pahl, G., Beitz, P., Nauka konstruowania, WNT, Warszawa, 1984.

[19] Reynolds, D.D., Falkenberg, R.J., A study of hand vibration on chipping and grinding operators, Part II: Four- degree-of freedom lumped parameter model of the vibration response of the human hand, Journal of Sound and Vibration, 95, 1984.

[20] Szücs, E., Modelowanie matematyczne $w$ fizyce i technice, Warszawa, WNT, 1997

[21] Śledziński, M., Ksztattowanie cech konstrukcyjnych tłumika drgań ubijaka pneumatycznego, Rozprawa doktorska, Politechnika Poznańska, Poznań, 2006.

[22] Śledziński, M., Badania układów „Człowiek-narzędzie udarowepodtoże”, Rozprawy nr 509, Wydawnictwo Politechniki Poznańskiej, Poznań, 2013.

[23] Tytyk, E., Projektowanie ergonomiczne, Wydawnictwo naukowe PWN, Warszawa - Poznań, 2001.

[24] Tytyk, E., Butlewski, M., Ergonomia $w$ technice, Wydawnictwo Politechniki Poznańskiej, Poznań, 2011.

[25] Wood, L.A., Suggs, C.W., Abrams, C.F., A distributed parameter dynamic model of the human hand-arm system, Journal of Sound and Vibration, 57, 2, 1978.

[26] Ziemiański, D., Identyfikacja i modelowanie wybranych zachowań dynamicznych układu człowiek-otoczenie, Rozprawa doktorska, Politechnika Krakowska, Kraków, 2011. 